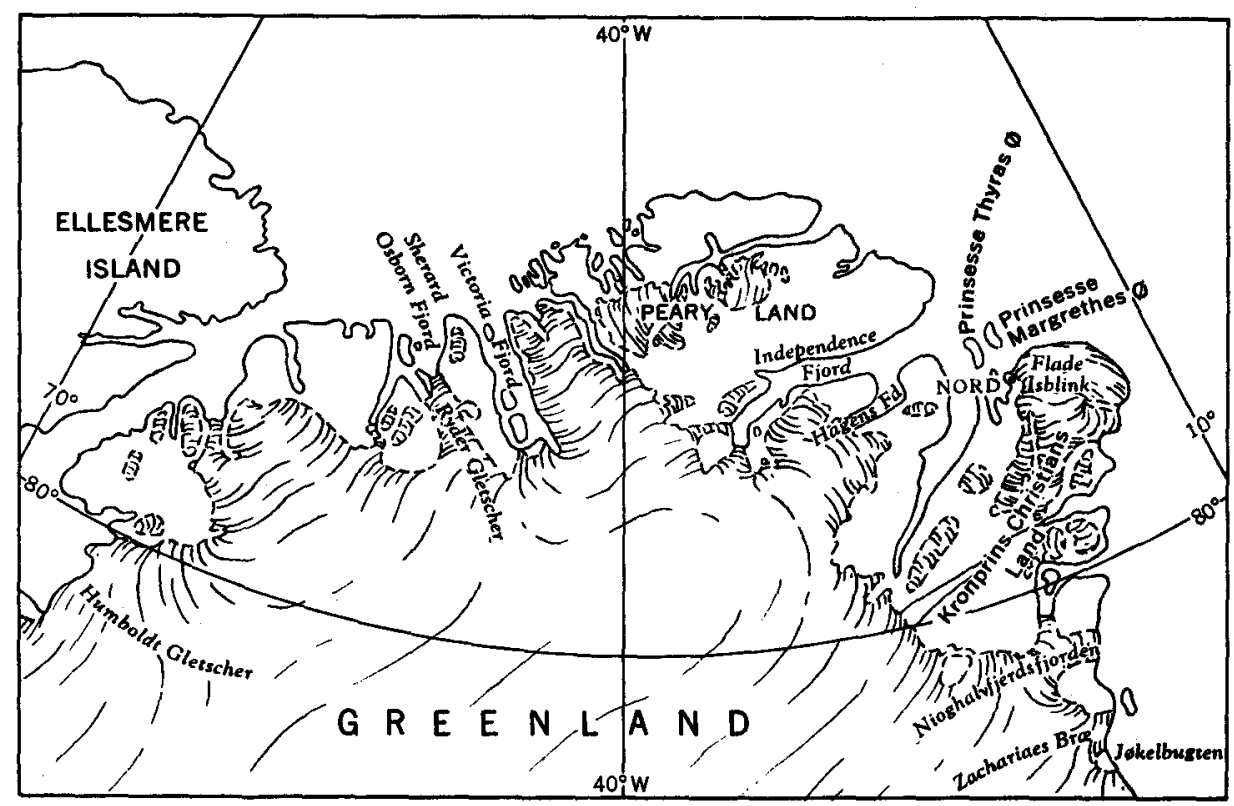

Fig. 1.

\title{
ICE ISLANDS: \\ EVIDENCE FROM NORTH GREENLAND
}

\section{J. V. Helk* and Moira Dunbar ${ }^{\dagger}$}

$\mathbf{F}$ lollowing the article on ice islands published in the July 1952 number of Arctic ${ }^{1}$, Captain Leverett G. Richards of the United States Air Force $\bar{R}^{2}$ erve ${ }^{2}$ sent us a coloured slide of a large piece of ice in northeast Greenland which showed considerable resemblance to the ice islands. He had taken the photograph near Prinsesse Thyras $\emptyset$, when flying supplies to the Nord weather station in Independence Fjord. Through Captain Richards we were put in touch with Lieutenant-Colonel J. V. Helk of the Danish Geodetic Institute, who has sent us a collection of air photographs of areas in north Greenland in which ice reminiscent of the Ellesmere shelf occurs. A few of these photographs are reproduced here with Colonel Helk's comments.

The areas in question are: Sherard Osborn and Victoria fiords, on the north coast; Kronprins Christians Land and Independence Fjord, in the northeast corner; and the east coast between $78^{\circ}$ and $80^{\circ} \mathrm{N}$. Colonel Helk, who from the first has been closely connected with the photographing of Greenland, is reasonably sure that these are the only areas in north Greenland where ice of this nature is to be found.

EDITor

*Chief, Photogrammetric Division, Geodetic Institute of Denmark.

†Arctic Research Section, Defence Research Board of Canada.

${ }^{1}$ Koenig, L. S. et al. 1952. "Arctic ice islands". Arctic, Vol. 5, pp. 67-103.

2Now aviation editor of The Oregonian. 


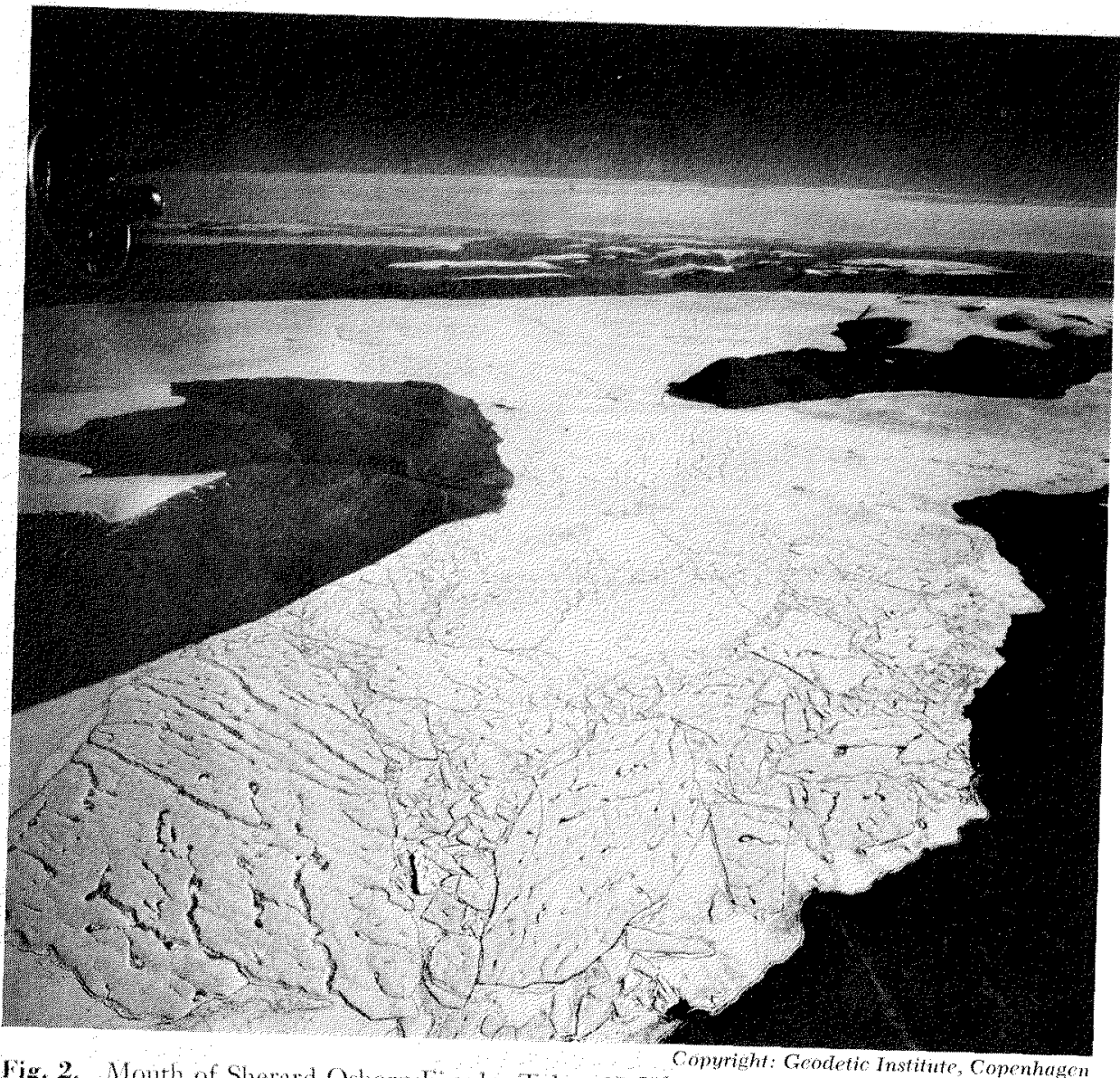

Fig. 2. Mouth of Sherard Oshom Fond Taken 27 Jnly 1952 at 4,000 metres (13,000 feet).

\section{Notes on the photographs. By J. V. Helk}

Sherard Osborn and Victoria fiords

Fig. 2 shows Sherard Osborn Fjord, looking up the fiord, with the snout of the Ryder Gletscher in the background. In the foreground are some of the large bergs from the glacier, the largest about $2 \frac{1}{2} \times 2$ miles (nautical miles). Fig. 3 shows the mouth of the fiord, with more bergs. The latter would be hard to distinguish from small ice islands.

The bergs in Victoria Fjord are in some respects like those in Fig. 2, but smaller and much more worn down by melting. Though somewhat similar to the Ellesmere shelf, the ice in these fiords lacks the large rolls typical of the shelf.

\section{Kronprins Cbristians Land}

The northern part of Kronprins Christians Land is covered by an isolated ice cap, Flade (flat) Isblink (Fig. 4). This ice cap is apparently inactive. On 


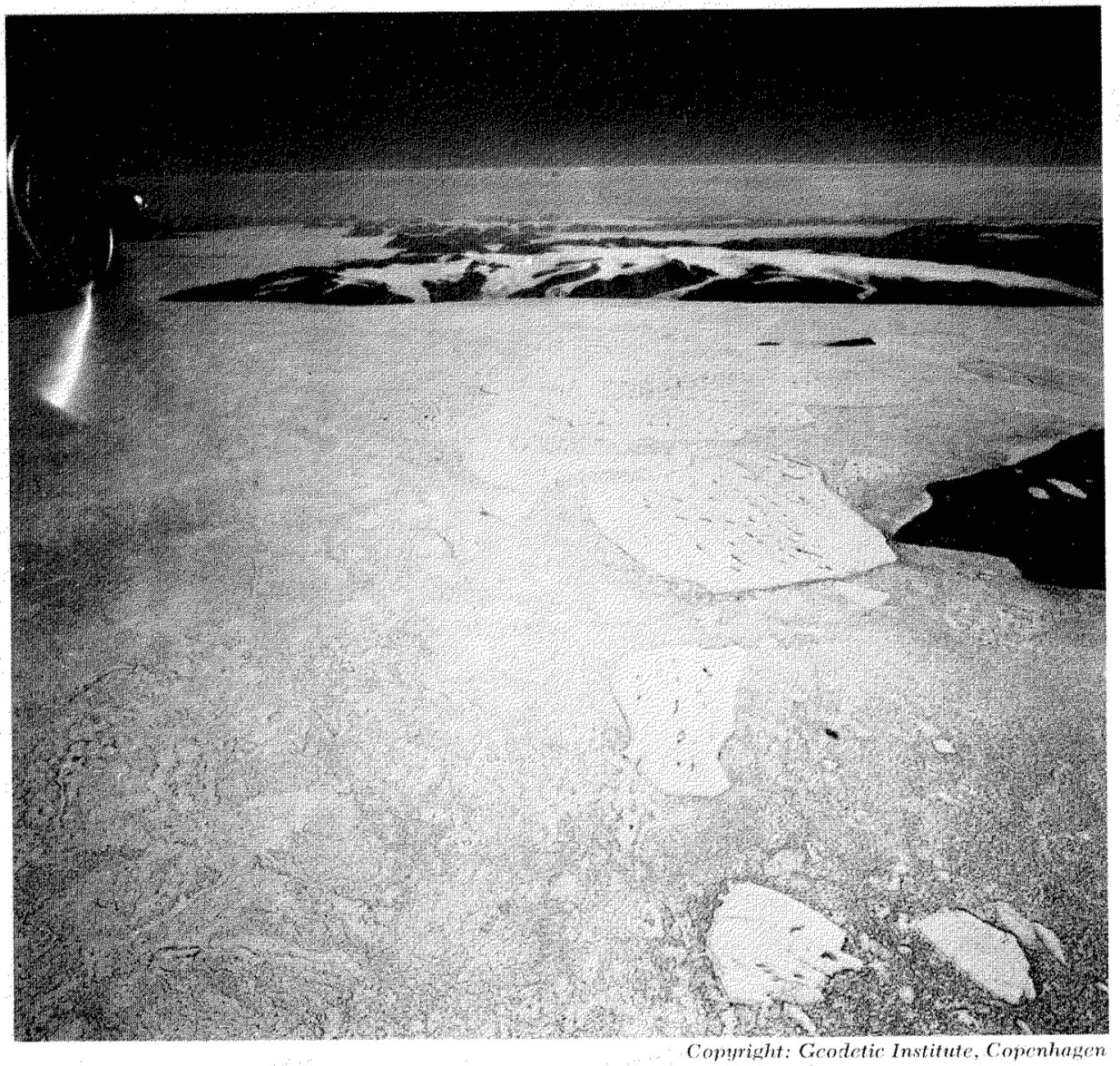

Fig. 3. Sherard Ostom Fjord, looking inland. Taken 27 July 1952 at 4,000 metres $(13,000 \mathrm{fect})$.

the east side it is stagnant and the northern edge appears to be disintegrating into flat-topped bergs.

\section{Prinsesse Thyras $\varnothing$}

Fig. 5 shows an "ice island" which lies between Prinsesse Thyras $\varnothing$ and Prinsesse Margrethes $\emptyset$. This "island" actually consists of two very different parts. The northern quarter is flat and appears to be without rolls, but there are narrow snowdrifts running north and south; the rest is slightly higher, especially in the middle, and has broad rolls running roughly east and west, with the north-south snowdrifts superimposed. The northern part looks very much like old sea ice, while the southern part resembles ice found on the east coast (Jøkelbugten, see Fig. 8). The "island" lies very close to Prinsesse Thyras $\varnothing$ but is not attached to it.

It is hard to tell whether this is a relic in situ of a larger ice shelf or whether it was formed elsewhere and drifted to its present position. The depth of water in the area is not known, but it seems likely from the number and 
flatness of the islands that it is shallow. The ice could therefore easily be grounded in situ. On the other hand it would be hard to explain why this piece should have resisted longer than the ice which must once have covered the islands. From available records it appears that the mean temperature in this area is rather lower than on the Peary Land coast and Independence Fjord, and the islands remain snow-covered for longer. Nevertheless the snow does melt and the fast ice breaks up in many seasons. It seems more likely that it has drifted to its present position, possibly from Flade Isblink, and grounded.

It is not known how long this "island" has been there, but it has been travelled over on the ground at least once. In 1952, after the photographs were taken, Count Eigil Knuth travelled along the east coast of Prinsesse Thyras $\emptyset$. The visibility was poor, but Knuth noticed strange uneven structures and black areas on the ice in this region.

\section{Hagens Fjord}

Fig. 6 shows a very large iceberg in Hagens Fjord, about $3 \times 5$ miles. This came from the glacier emptying into this fiord and the large number of smaller bergs indicate the glacier's activity. The large berg, though less regular in surface pattern than most ice islands, shows signs of parallel rolls, especially in the lower left corner.

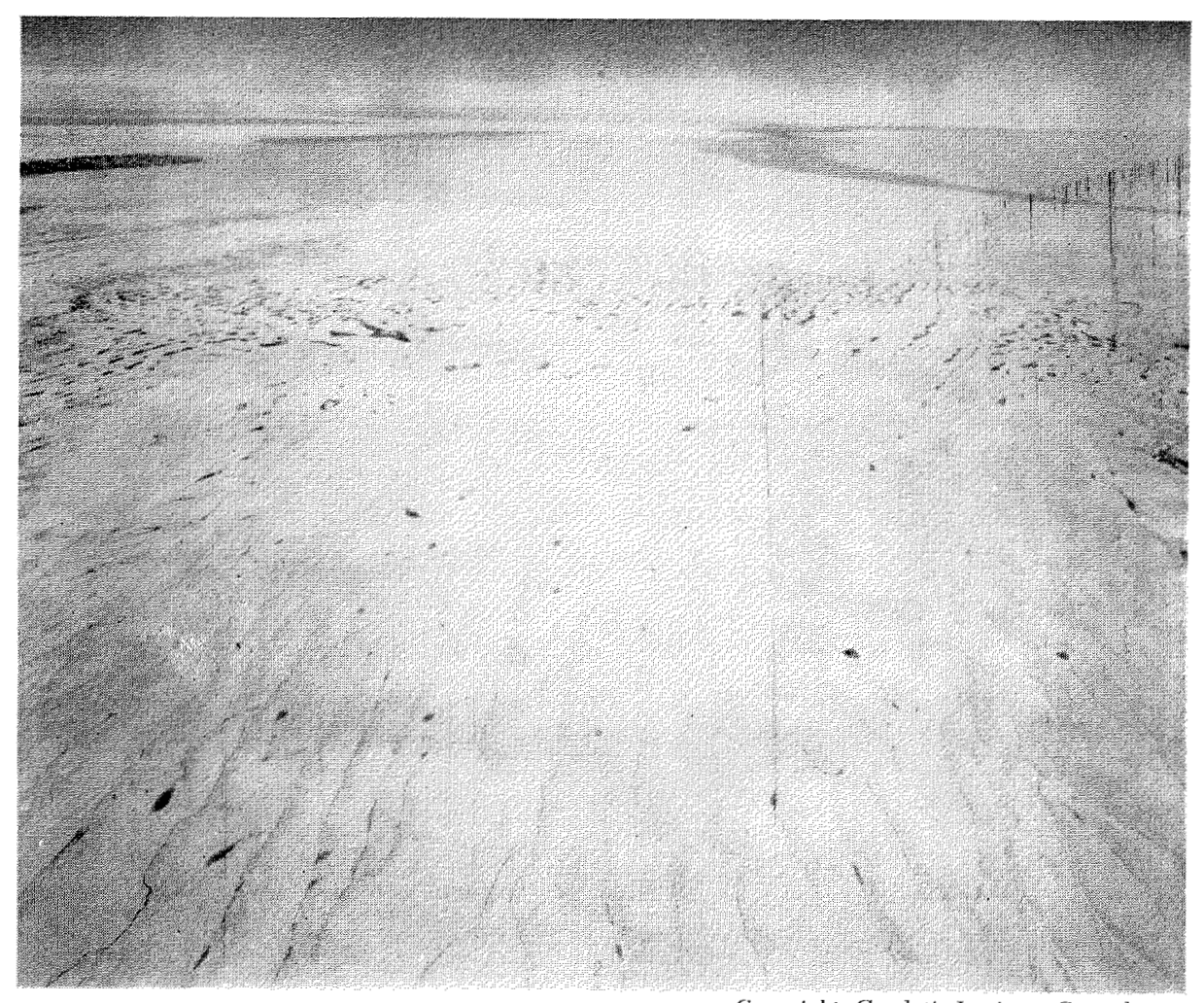

Copyright: Geodetic Institute, Copenhagen

Fig. 4. Flade Isblink, Prinsesse Thyras $Q$ in left background. Taken 30 July 1951 at 4,000 metres $(13,000$ feet $)$. 


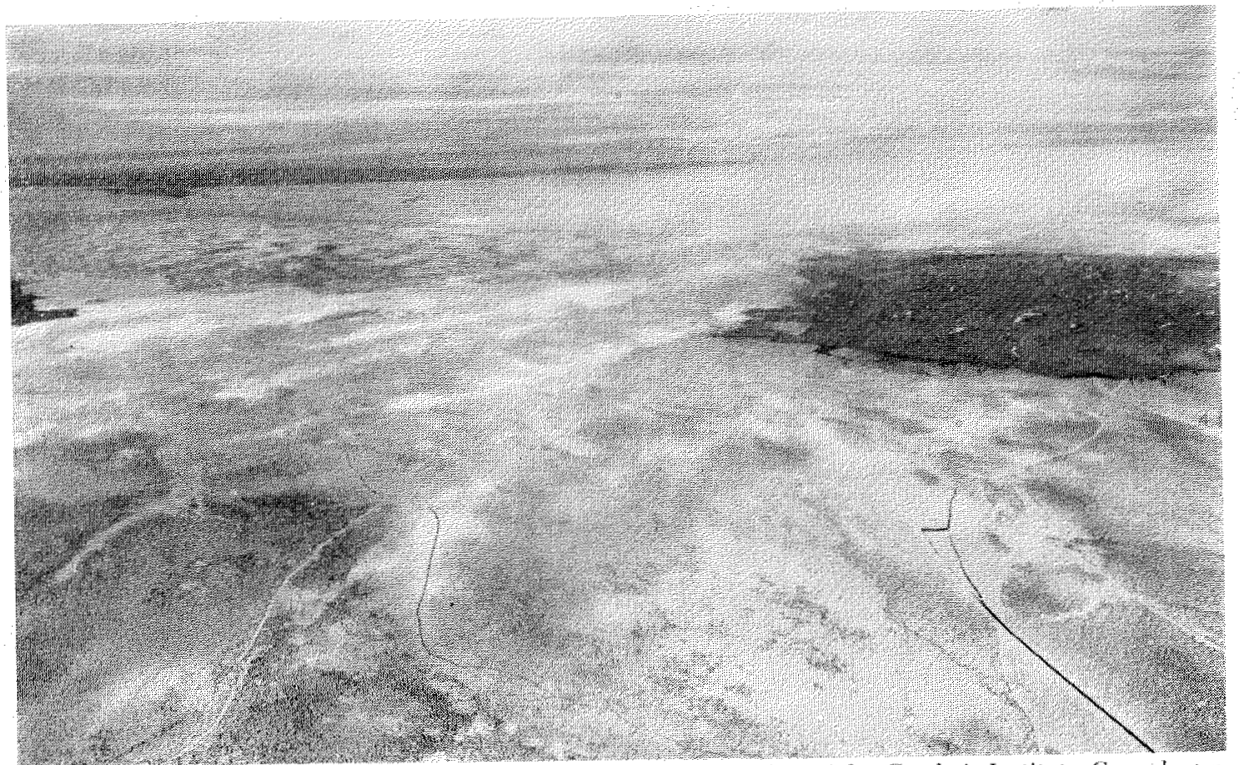

Copyright: Geodetio Institute, Copenlagen

Fig. 5. "Lee island" off Prinsesse Thyras 0 , part of which is just yisible on the left Taken 11 August 1951 at 3,600 metres $(11,800$ fect $)$.

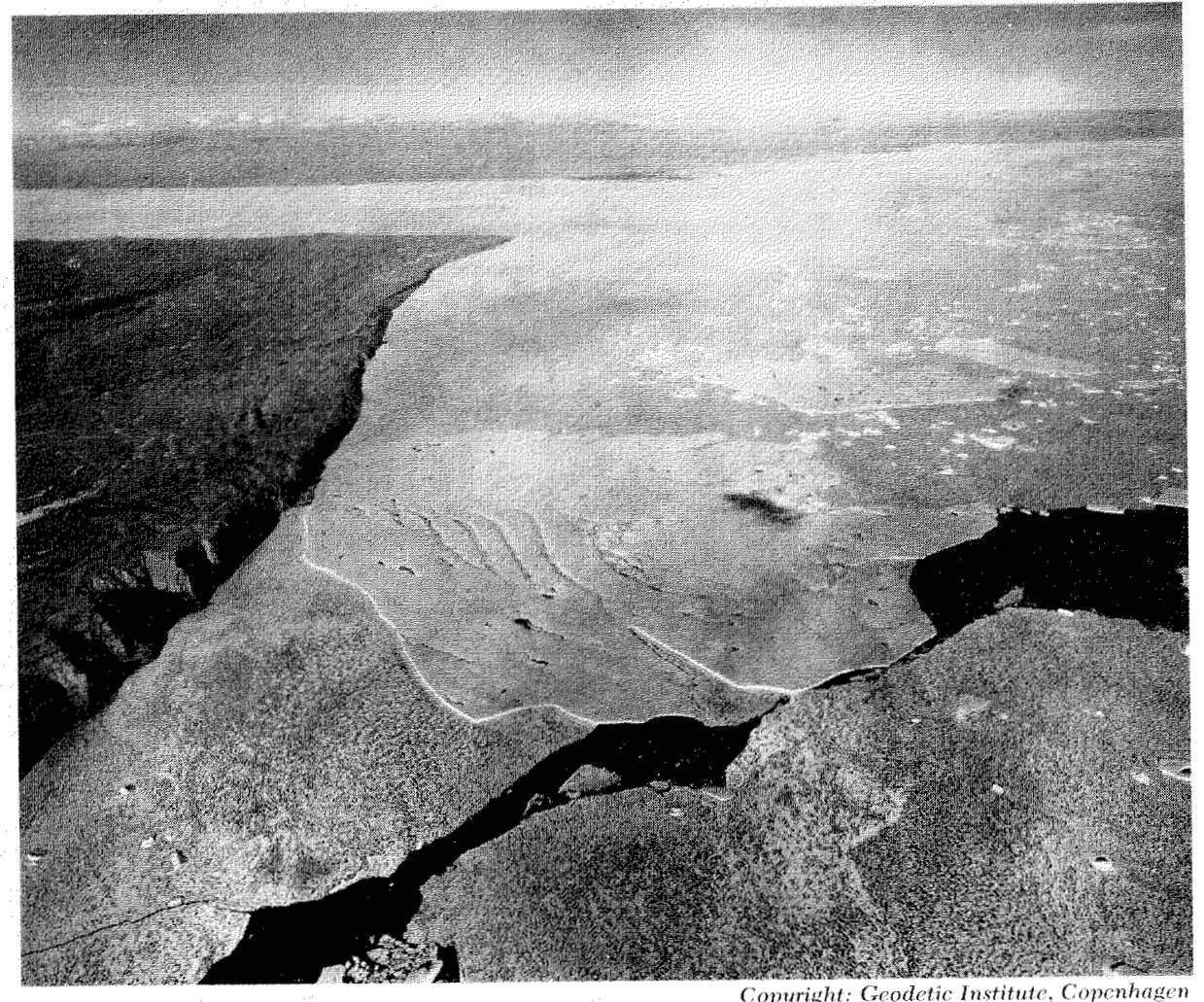

Fig. 6. Targe jceberg in Hagens Fjord, looking north. Taken 29 July 1951 at 4,000 metres $(13,000$ feet $)$. 


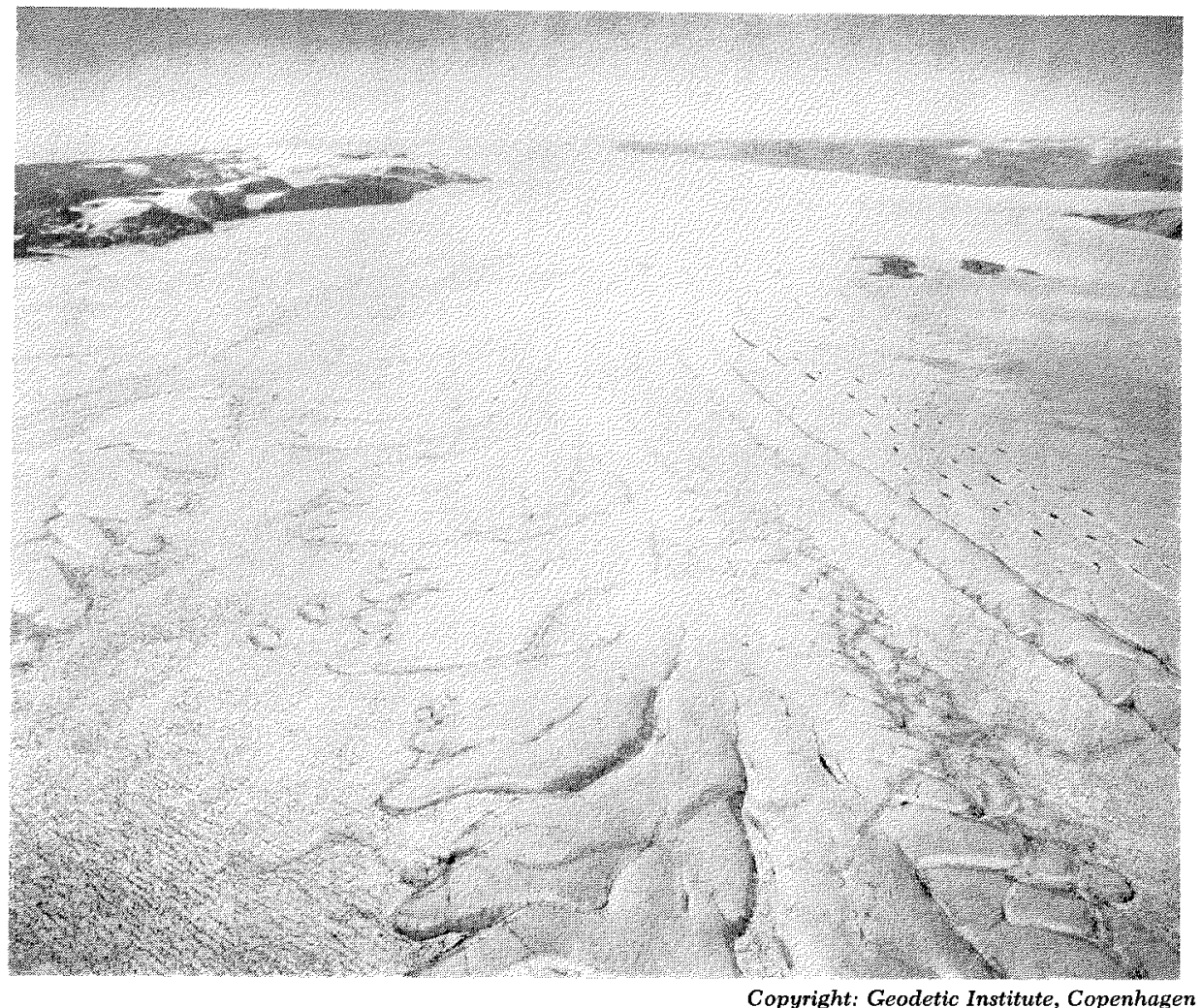

Fig. 7. Nioghalvfjerdsfjorden, looking inland up the glacier. Taken 15 August 1950, at 4,000 metres $(13,000$ feet $)$.

East coast between $78^{\circ}$ and $80^{\circ} \mathrm{N}$.

Fig. 7 shows Nioghalvfjerdsfjorden (Seventy-nine Fiord), looking up the glacier from the sea. This glacier is moving rather slowly and produces few bergs. These are held fast for long periods by the sea ice, which seldom breaks up.

Fig. 8. A little farther south Zachariaes Bræ (glacier) empties into the north part of J $\phi$ kelbugten (Glacier bay). Here too the movement is very slow. The photograph is taken looking inland towards the glacier.

Fig. 9. This photograph shows large fields of ice broken presumably from Zachariaes Bræ. In this part of the bay the sea ice breaks up almost every year, which accounts for the more broken appearance and sharper edges of the pieces.

\section{Comments on the photographs. By Moira Dunbar}

These photographs of north Greenland, showing ice of undoubted glacial origin, add evidence in support of the theory that the Ellesmere Ice Shelf is also of glacial origin. Some of the Greenland ice is so like the Ellesmere shelf ice and the ice islands that it would be hard to distinguish them. Indeed some 


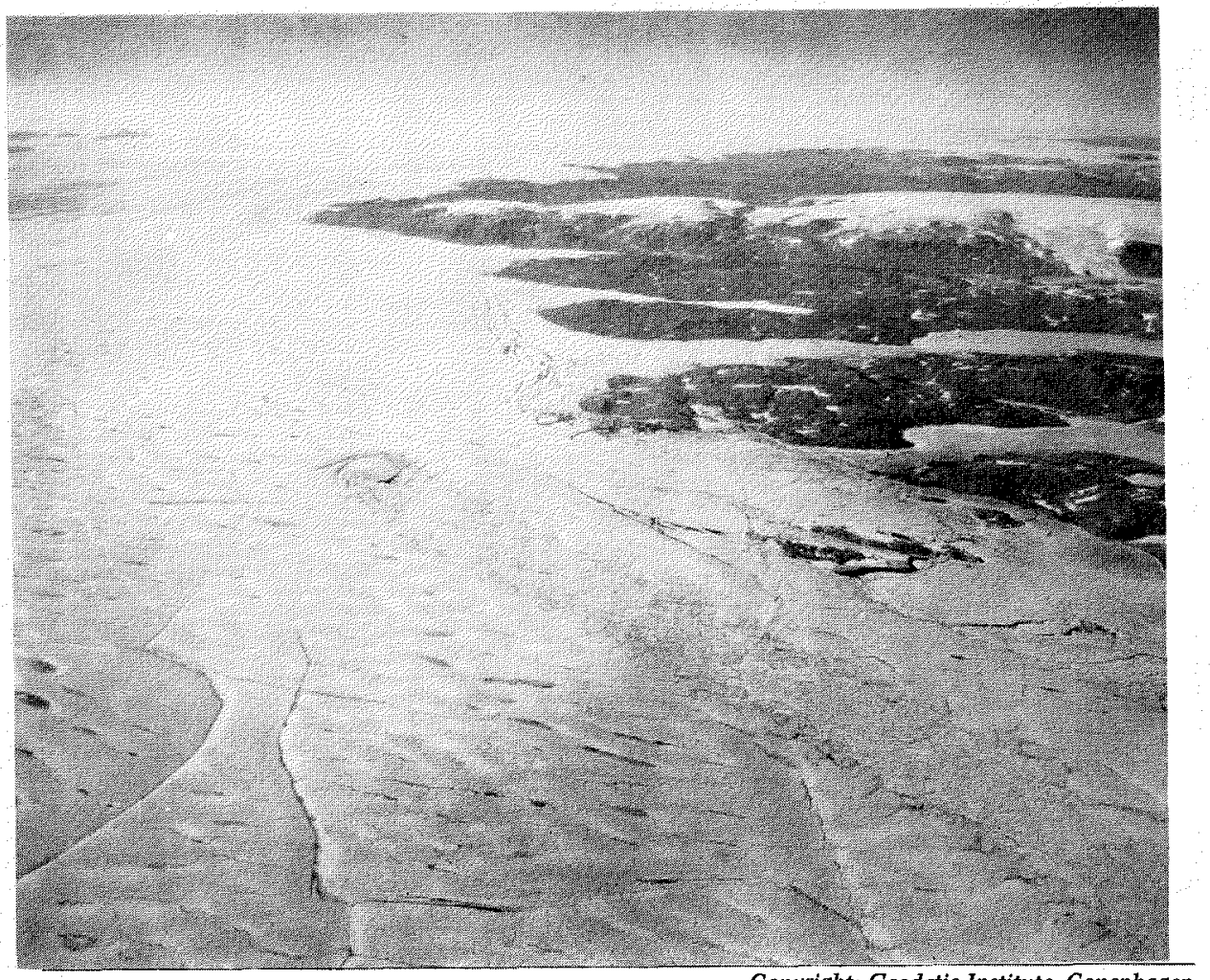

Copyright: Geodetic Institute, Copenhagen

Fig. 8. Zachariaes Bræ, Jøkelbugten, looking inland. Taken 15 August 1950 at 4,000 metres $(13,000$ feet $)$.

of the ice islands photographed in the Canadian Arctic might have come from the Ryder Gletscher-any from the Flade Isblink or the east coast would be unlikely to move westwards round the north coast of Greenland but would go south down the east coast and melt.

At this time Mr. G. F. Hattersley-Smith has recently returned from a visit to the Ellesmere Ice Shelf and will shortly be publishing his preliminary findings. It is therefore not a suitable moment to theorize from air photo evidence only. The following points, however, are worth noting for future consideration when ground data are available as well.

The north coast of Greenland, like that of Ellesmere Island, is a fiord coast with an elevation in the highlands of 3-4,000 feet. The Greenland fiords are longer and wider than the Ellesmere ones but the general characteristics are the same and the fiord glaciers have very gentle gradients. It is fair to assume that at some time in the very recent past, geologically speaking, the same ice cap covered both, thrusting a common front towards the Arctic Ocean. This, when it ceased to be active, would probably look not unlike the Flade Isblink does today (Fig. 4). A glance at the map will show that if the Flade Isblink is considered as part of such an ice cap it would be flowing eastwards at this point. Thus the north-south rolls on Flade Isblink, which apparently run 


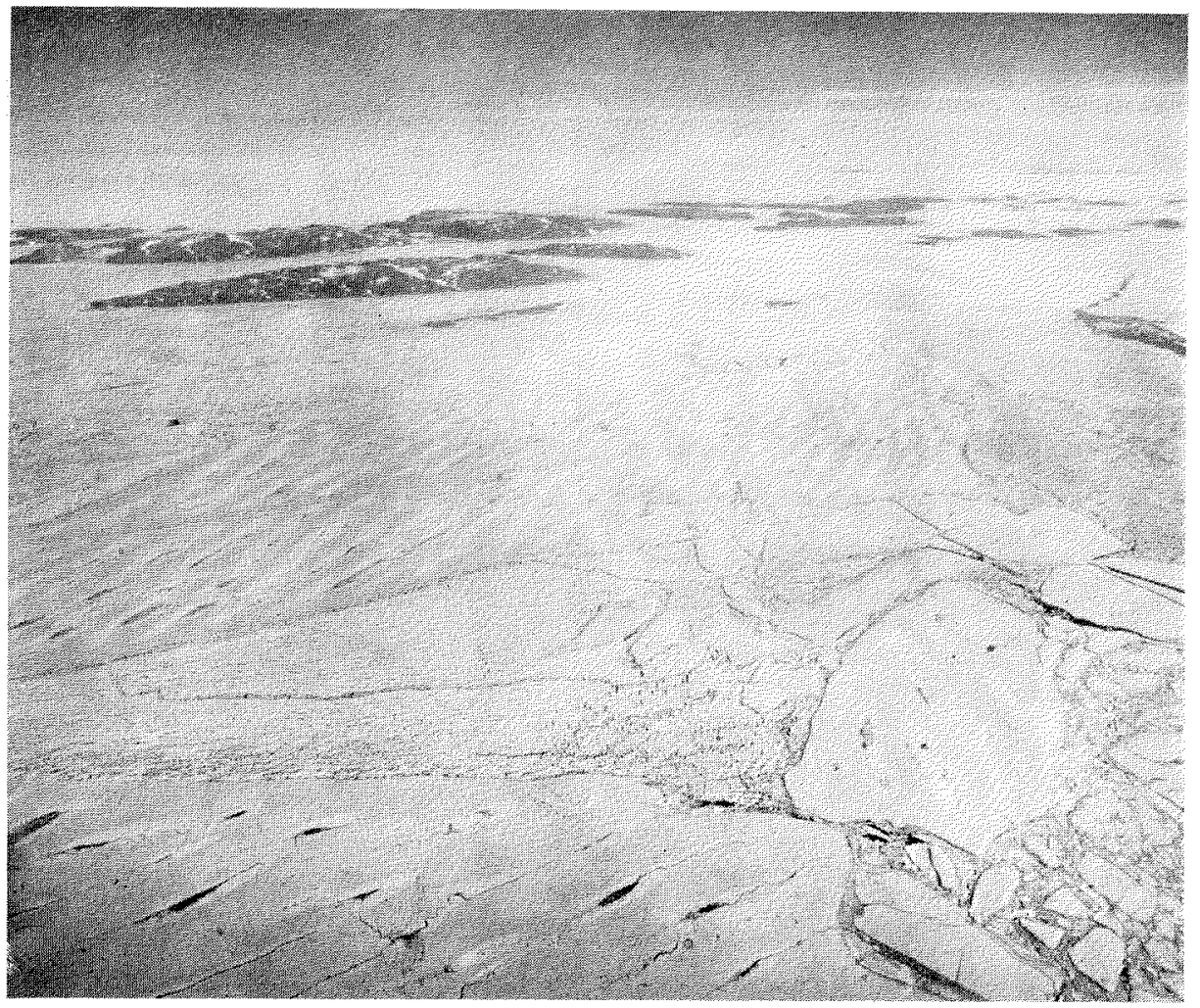

Copyright: Geodetic Institute, Copenhagen

Fig. 9. South part of Jøkelbugten, looking east. Taken 15 August 1950 at 4,000 metres $(13,000$ feet $)$.

with instead of across the direction of flow, would actually show the same direction as is typical of the Ellesmere Ice Shelf.

As the ice retreated nunataks would appear and melting would be accelerated by the heating of the rock, so that it is in no way extraordinary to suppose that the land ice might disappear, leaving a relic fringing the coast which would melt much more slowly and which could break away only in years when the sea ice around it broke up. This is not believed to occur very frequently on the north coast of Ellesmere Island even today, and it may reasonably be supposed that it occurred at least as seldom when the glaciers were nearer the coast. Why the fringing ice has apparently all gone from the Greenland coast, where the glaciers are much more active than in Ellesmere Island, is not immediately clear. It is possible however that some local phenomenon, such as ocean currents, may cause the sea ice to break up more frequently in this region.

The ice on the east coast is the most interesting and the most like the Ellesmere Ice Shelf. One very intriguing feature appears in Figs. 7 and 8; these show small islands which give the impression of having sailed into the ice like so many icebreakers and left channels behind them filled with ordinary sea 
ice. It is hard to explain these channels. Presumably the glacier has been diverted around the islands and continued seawards, but it is curious that the ice has neither overridden the very low islands nor flowed together again after the islands are passed. In Fig. 7 too the rolls run parallel to the direction of flow. This direction continues right up the glacier, though farther up there is also a less clearly marked pattern running at right angles to the flow. At the head of the glacier there are no apparent rolls but the surface is heavily crevassed, the crevasses becoming closed or filled in as the gradient flattens out. Most intriguing of all is the series of almost identical pieces shaped like birds' wings in Fig. 7. How they have been formed I cannot even guess, but the pattern seems too marked to be accidental.

The suggestion that Sherard Osborn and Victoria fiords are the only areas on the north coast of Greenland where ice comparable to the Ellesmere Ice Shelf exists today is particularly interesting. In the July 1952 number of Arctic (p. 94), I mentioned that Lockwood of Greely's expedition (1881-4) referred once or twice to "undulating ice" on the north coast of Greenland. In fact all these references were made in the vicinity of these fiords.

The results of Hattersley-Smith's expedition and the second one that is planned for 1954 should do much to clear up the problem. I believe however that although ground investigation is of course essential to the study, many significant features are only to be found from an examination of these and other air photographs, and that whatever the final explanation of the Ice Shelf, it will involve the course of events in the glacial history of Greenland as well as of Ellesmere Island. 